\title{
MENGAKSES DAN MEMONITOR KEMAMPUAN BERPIKIR KREATIF MATEMATIS SISWA KELAS V SEKOLAH DASAR DALAM PEMBELAJARAN MATEMATIKA
}

\author{
Nia Kurniawati \\ SDN 1 Jambudipa \\ Arkaniku15@gmail.com
}

Diterima: 30 Juni 2018

\begin{abstract}
ABSTRAK
Pengembangan kemampuan berpikir kreatif merupakan salah satu fokus dalam pembelajaran matematika. Melalui pembelajaran matematika, siswa diharapkan memiliki kemampuan berpikir logis, analitis, sistematis, kritis, dan kreatif, serta memiliki kemampuan untuk memecahkan masalah. Penelitian ini bertujuan untuk memperoleh gambaran tentang sikap dan kemampuan berpikir kreatif matematis siswa kelas V SD Negeri Jambudipa I dalam pembelajaran matematika. Penelitian ini menggunakan pendekatan kualitatif ini dipilih karena, lebih sensitif dan adaftif terhadap peran dan pengaruh yang ditimbulkan, disamping itu peneliti mencoba menggali, mengeksplorasi, menggambarkan serta mengembangkan bagaimana pengetahuan itu dibentuk maka peneliti menggunakan penelitian kualitatif, dengan metode Grounded Theory. Penelitian ini dilakukan di Sekolah Dasar Negeri Jambudipa I, yang terletak di komplek Lapang Jagaraksa Desa Jambudipa Kecamatan warungkondang Kabupaten Cianjur. Dalam penelitian ini yang menjadi populasi penelitian dua orang tenaga pengajar (guru kelas V) dan siswa. Sedangkan subjek dalam penelitian ini adalah siswa kelas V A dengan jumlah siswa 35 orang, terdiri dari 15 laki -laki dan 20 perempuan.Berdasarkan hasil penelitian diketahui bahwa dari perencanaan pembelajaran guru sudah terbiasa membuatnya, untuk menggungkap kemampuan berpikir kreatif matematis guru mengunakan pendekatan Contextual Teaching Learning (CTL) juga menngunakan berbagai alat peraga yang diharapkan mampu menjembatani kemunculan berpikir kreatif matematis. Adapun indikator dari berpikir kreatif matematis adalah; kemapuan berpikir lancar, kemampuan berpikir luwes, kemampuan berpikir orisinal, kemampuan merinci dan kemampuan mengevaluasi. Dalam kegiatan pembelajaran siswa terlihat antusias, dan senang ketika mengikuti pelajaran, ini dikarnakan cara mengajar guru yang berbeda dengan hari-hari sebelumnya / konvensional.
\end{abstract}

Kata Kunci: pembelajaran, pendidikan, berpikir kreatif matematis

\section{PENDAHULUAN}

Pengembangan kemampuan berpikir kreatif merupakan salah satu fokus pembelajaran matematika. Melalui pembelajaran matematika, siswa diharapkan memiliki kemampuan berpikir logis, analitis, sistematis, kritis, dan kreatif, serta memiliki kemampuan bekerja sama (Depdiknas, 2004). Pengembangan kemampuan berpikir kreatif memang perlu dilakukan karena kemampuan ini merupakan salah satu kemampuan yang dikehendaki dunia kerja (Career CenterMaine Department of Labor USA, 2004). Tidak diragukan lagi bahwa kemampuan berpikir kreatif juga menjadi penentu keunggulan suatu 
bangsa. Daya kompetitif suatu bangsa sangat ditentukan oleh kreativitas sumber daya manusianya.

Hasil pengamatan penulis dan wawancara dengan guru kelas V SDN Jambudipa I kecamatan Warungkondang Kabupaten Cianjur, diketahui bahwa nilai matematika siswa rendah, hal ini terjadi karena dalam pembelajaran matematika secara konvensional, siswa jarang sekali diminta untuk mengkombinasikan ide - idenya. Dari gambaran di atas perlu adanya perbaikan dalam pola mengajar matematika, Pendekatan Contextual Teaching Learning (CTL) dianggap mampu meningkatkan kemapuan berpikir kreatif matematis siswa karena pendekatan CTL berfocus pada siswa sebagai pembelajar yang aktif dan memberikan rentang yang luas tentang peluang belajar bagi siswa dalam memecahkan masalah matematika. Dalam penelitian ini akan menganalisis kemampuan berpikir kreatif matematis siswa kelas V Sekolah Dasar dalam pembelajaran matematika dengan menggunakan pendekatan Contextual Teaching Learning (CTL).

\section{Pembelajaran Matematika di SD}

Istilah matematika diambil dari bahasa Yunani, mathematike, yang berarti "relating to learning". Perkataan mathematike berhubungan sangat erat dengan sebuah kata lainnya yang serupa, yaitu mathanein yang mengandung arti belajar (berpikir). Jadi berdasarkan etimologis (Elea Tinggih dalam Erman Suherman, 2003:16), perkataan matematika berarti "ilmu pengetahuan yang diperoleh dengan bernalar". Johnson dan Rising (1972) dalam bukunya mengatakan bahwa matematika adalah pola pikir, pola mengorganisasikan, pembuktian yang logik, matematika itu adalah bahasa yang menggunakan istilah yang didefinisikan dengan cermat, jelas, dan akurat, representasinya dengan simbol dan padat, lebih berupa bahasa simbol mengenai ide dari pada mengenai bunyi.

\section{Berpikir Kreatif Matematis}

Berpikir merupakan suatu kegitan mental yang dialami seseorang bila mereka dihadapkan pada sesuatu masalah atau situasi yang harus dipecahkan. Ketika seseorang merumuskan suatu masalah, memecahkan masalah, ataupun ingin memahami sesuatu, maka ia melakukan suatu aktivitas berfikir. Apa itu berpikir kreatif? Isaksen et al (Grieshober, 2004) mendefinisikan berpikir kreatif sebagai proses konstruksi ide yang menekankan pada aspek kelancaran, keluwesan, kebaruan, dan keterincian. Sementara menurut Martin (2009), kemampuan berpikir kreatif adalah kemampuan untuk menghasilkan ide atau cara baru dalam menghasilkan suatu produk. Pada umumnya, 
berpikir kreatif dipicu oleh masalah-masalah yang menantang. Pentingnya kreativitas dalam matematika dikemukakan oleh Bishop (Pehnoken, 1997) yang menyatakan bahwa seseorang memerlukan dua keterampilan berpikir matematis, yaitu berpikir kreatif yang sering diidentikkan dengan intuisi dan kemampuan berpikir analitik yang diidentikkan dengan kemampuan berpikir logis.

\section{Mengukur Kemampuan Berpikir Kreatif Matematis}

Menurut Worthington (2006), mengukur kemampuan berpikir kreatif siswa dapat dilakukan dengan cara mengeksplorasi hasil kerja siswa yang merepresentasikan proses berpikir kreatifnya. Getzles dan Jackson (Silver, 1997) mengemukakan cara untuk mengukur kemampuan berpikir kreatif matematis, yakni dengan soal terbuka (open-ended problem). Menurut Becker dan Shimada (Livne, 2008), soal terbuka (open-ended problem) adalah soal yang memiliki beragam jawab. Dalam hal ini, aspek-aspek yang diukur adalah kelancaran, keluwesan, dan kebaruan, dan keterincian. Kelancaran berkaitan dengan banyaknya solusi. Keluwesan berkaitan dengan ragam ide. Kebaruan berkaitan dengan keunikan jawaban siswa. Sedangkan aspek keterincian berkaitan keterincian dan keruntutan jawaban.

\section{Contextual Teaching Leanrning (CTL)}

Contextual Teaching Leanrning (CTL) merupakan proses pembelajaran yang holistik dan bertujuan membantu siswa untuk memahami makna materi ajar dengan mengaitkannya terhadap konteks kehidupan mereka sehari-hari (konteks pribadi, sosial dan kultural), sehingga siswa memiliki pengetahuan/ ketrampilan yang dinamis dan fleksibel untuk mengkonstruksi sendiri secara aktif pemahamannya. Pembelajaran berbasis CTL mempunyai beberapa karakter khas yang memang seharusnya ada dalam CTL. Selain itu, ada beberapa faktor penting pula yang menjadi pertimbangan dalam pembelajaran CTL. Berikut ini karakter: kerjasama antar peserta didik dan guru (cooperative),saling membantu antar peserta didik dan guru (assist),belajar dengan bergairah (enjoyfull learning),pembelajaran terintegrasi secara kontekstual,menggunakan multimedia dan sumber belajar,cara belajar siswa aktif (student active learning),sharing bersama teman (take and give),siswa kritis dan guru kreatif, dinding kelas dan lorong kelas penuh dengan karya siswa, laporan siswa bukan hanya buku rapor, tetapi juga hasil karya siswa, laporan hasil pratikum, karangan siswa dan sebagainya. 


\section{METODOLOGI PENELITIAN}

Metode penelitian yang digunakan yaitu Grounded Theory. Grounded Theory merupakan prosedur penelitian kualitatif yang sistematik, dimana peneliti menerangkap konsep, proses, tindakan, atau interaksi mengenai suatu topik pada level konseptual yang luas. Pendekatan Grounded Theory menyusun teori berdasarkan data lapangan. Data yang diperoleh secara induktif bukan dimaksudkan untuk menguji hipotesis, tetapi untuk melakukan abstraksi berdasarkan data yang telah dikumpulkan yang saling berhubungan dan dipisah-pisahkan. Dalam Grounded Theory ada beberapa strategi analisis kunci yang dikemukakan adalah :Koding adalah proses untuk membuat kategorisasi data kualitatif dan juga untuk menguraikan implikasi dan rincian dari kategori - kategorinya. Memoing ( membuat memo ) adalah proses mencatat pemikiran - pemikiran dan gagasan - gagasan dari peneliti sewaktu hal - hal itu muncul selama studi. Diagram terpadu dan sesi digunakan untuk menarik rincian menjadi satu, untuk membantu agar data itu menjadi berarti dengan mengarahkan diri kepada teori yang muncul.

Subjek penelitian ini adalah siswa kelas V SDN Jambudipa I di Kecamatan Warungkondang Kabupaten Cianjur. Pemilihan subjek penelitian dilakukan dengan menggolongkan siswa kedalam tiga kategori yaitu kategori tinggi, sedang dan rendah. Untuk menentukannya maka dilihat dari peringkat siswa di kelas. Ada beberapa alasan pemelihan subjek penelitian yaitu :1) Ingin mengetahui kemampuan berpikir kreatif matematis siswa kelas V Sekolah Dasar di SD Negeri Jambudipa I, 2) SD Negeri Jambudipa 1 merupakan SD centre di Kecamatan Warungkondang sehingga menbutuhkan inovasi - inovasi dalam pendidikan khususnya dalam proses pembelajaran,3) Belum adanya penelitian yang berorientasi kepada kemampuan berpikir kreatif matematis sebelumnya di SD Negeri Jambudipa I.

\section{HASIL DAN PEMBAHASAN}

Pada bagian pembahasan data dianalisis dengan menggunakan model interaktif (Milles : 2011 ). Secara garis besar analis data berlangsung dalam tiga tahapan. Tahap pertama pengkodean atau koding, tahap kedua kategorisasi, dan tahap ketiga pengembangan teori. Kategori sesungguhnya mendeskripsikan data dan juga menginterpretasi data, kategori - kategori itu kemudian dihubungkan satu sama lain untuk membentuk teori. Untuk mengakses dan memonitor kemampuan berpikir kreatif matematis siswa kelas V dalam pembelajaran matematika, peneliti menggunakan hasil observasi, dan 
hasil evaluasi siswa sebagai alat untuk mengakses dan memonitor kemampuan berpikir kreatif matematis.

\section{Hasil Observasi Dalam Proses Kegiatan Pembelajaran Matematika}

Untuk hasil observasi pada proses pembelajaran matematika, pada materi volume balok, kemampuan berpikir kreatif matematis muncul pada saat siswa melaporkan hasil diskusi di depan kelas:

Tabel 1. Faktorisasi dari Bilangan 72

\begin{tabular}{ccccc}
\hline NO & PANJANG & LEBAR & TINGGI & VOLUME \\
\hline $\mathbf{1 .}$ & 12 & 3 & 2 & 72 \\
\hline $\mathbf{2 .}$ & 72 & 1 & 1 & 72 \\
\hline $\mathbf{3 .}$ & 1 & 1 & 72 & 72 \\
\hline $\mathbf{4 .}$ & 3 & 2 & 12 & 72 \\
\hline $\mathbf{5 .}$ & 12 & 1 & 6 & \\
\hline & DST & & & \\
\hline
\end{tabular}

Sebenarnya nilai $\mathrm{P}$, L, dan $\mathrm{T}$ merupakan faktorisasi dari bilangan 72 . Namun demikian pemfaktoran ini disusun menggunakan bantuan, dengan cara menyusun kubus satuan itu sehingga menjadi berbagai bentuk balok. Disini diperlukan kecermatan siswa untuk menghitung berapa panjangnya, berapa lebarnya, dan berapa tingginya.Berikut ini adalah salah satu hasil kerja siswa:

Tabel Kemunculan Indikator - Indikator Berpikir Kreatif Matematis

\begin{tabular}{|c|c|c|c|}
\hline No & Indikator & Kriteria & Keterangan \\
\hline 1. & $\begin{array}{l}\text { Keterampilan } \\
\text { berpikir lancar }\end{array}$ & 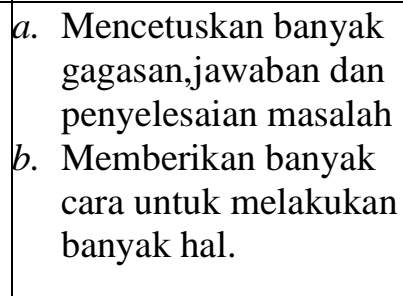 & $\begin{array}{l}\text { a.Muncul.Mampu memciptakan } \\
\text { banyak model dari satu volume } \\
\text { balok, sampai } 21 \text { model. } \\
\text { b.muncul .dalam mencari bangun } \\
\text { datar lain yang sama luasnya } \\
\text { dengan persegi panjang. }\end{array}$ \\
\hline 2. & $\begin{array}{l}\text { Keterampilan } \\
\text { berpikir luwes }\end{array}$ & $\begin{array}{ll}a . & \text { Menghasilkan } \\
& \text { banyak gagasan dan } \\
& \text { jawaban yang } \\
& \text { berfareasi. } \\
b . & \text { Dapat melihat suatu } \\
& \text { masalah dari sudut } \\
\text { pandang yang } \\
\text { berbeda }\end{array}$ & $\begin{array}{l}\text { a. Muncul . nilai tertinggi untuk } \\
\text { menciptakan model volume } \\
\text { balok dari } 72 \text { kubus satuan } \\
\text { adalah } 21 \text { model. } \\
\text { b. Tidak muncul }\end{array}$ \\
\hline
\end{tabular}




\begin{tabular}{|c|c|c|c|}
\hline 3. & $\begin{array}{l}\text { Keterampilan } \\
\text { berpikir orisinil }\end{array}$ & $\begin{array}{l}\text { a. Mampu melahirkan } \\
\text { hal yang baru dan } \\
\text { unik } \\
\text { b. Melahirkan cara yang } \\
\text { tidak lazim untuk } \\
\text { mengungkapkan diri } \\
\end{array}$ & $\begin{array}{l}\text { a. Muncul. Untuk volome balok } \\
\text { dengan model } \mathrm{p}=72, \mathrm{~L}=1, \mathrm{~T} \\
=1 \\
\text { b. Muncul. Untuk volome balok } \\
\text { dengan model } \mathrm{p}=72, \mathrm{~L}=1, \mathrm{~T} \\
=1\end{array}$ \\
\hline 4. & $\begin{array}{l}\text { Keterampilan } \\
\text { merinci }\end{array}$ & $\begin{array}{l}\text { a. Mampu memperkaya } \\
\text { dan mengembangkan } \\
\text { suatu gagasan } \\
\text { b. Memperinci detail - } \\
\text { detail dari suatu } \\
\text { gagasan sehingga } \\
\text { lebih menarik. }\end{array}$ & $\begin{array}{ll}\text { a. } & \text { Muncul ketika menggambar } \\
\text { segi tiga yang mempunyai } 2 \\
\text { sudut tumpul. } \\
\text { b. } \\
\text { Muncul ketika membuat / } \\
\text { membagi gambar segi tiga } \\
\text { menjadi beberapa bagian segi } \\
\text { tiga yang berukuran kecil. }\end{array}$ \\
\hline 5. & $\begin{array}{l}\text { Keterampilan } \\
\text { mengevaluasi }\end{array}$ & $\begin{array}{l}\text { Menentukan patokan } \\
\text { penilaian sendiri } \\
\text { danmenentukan apakah } \\
\text { suatu pertanyaan atau } \\
\text { gagasan benar atau tidak } \\
\text { benar }\end{array}$ & $\begin{array}{l}\text { Muncul ketika mengevaluasi } \\
\text { hasil kerja kelompok didepan } \\
\text { kelas ( memperagakan / } \\
\text { menggambarkan segi empat yang } \\
\text { disebutkan oleh guru kemudian } \\
\text { menyebutkan unsur - unsurnya. ) }\end{array}$ \\
\hline
\end{tabular}

Tabel 2. Data Hasil Tes Siswa Keterampilan Berpikir Kreatif Matematis Rangkuman Jawaban Siswa Setiap Soal Tes

\begin{tabular}{|c|c|c|c|c|}
\hline No & Soal & Pembahasan & $\mathrm{N}=35$ & $\%$ \\
\hline 1. & $\begin{array}{lr}\text { Berapa } & \text { volume } \\
\text { sebuah } & \text { balok } \\
\text { apabila } & \text { diketahui } \\
\text { salah } & \text { satu } \\
\text { rusuknya } & \text { adalah } \\
12 \mathrm{~cm} ? & \end{array}$ & $\begin{array}{l}\text { a. Siswa menuliskan } \\
\text { kemungkinanpanjang rusuk } 12 \text {. } \\
\text { b. Siwa menuliskan } 4 \text { kemungkinan } \\
\text { panjang ruruk } 12 \text {. } \\
\text { c. Siwa menuliskan } 4 \text { kemungkinan } \\
\text { panjang ruruk 12, namun salah satu } \\
\text { jawabannya salah. } \\
\text { d. Siswa menuliskan } 5 \text { kemungkinan } \\
\text { panjang rusuk 12. } \\
\text { e. Siswa menuliskan } 5 \text { kemungkinan } \\
\text { panjang rusuk 12, namun salah satu } \\
\text { jawabannya salah. } \\
\text { f. Siswa menuliskan } 6 \text { kemungkinan } \\
\text { panjang rusuk } 12 \text {. } \\
\text { g. Siswa menuliskan } 7 \text { kemungkinan } \\
\text { panjang rusuk 12. } \\
\text { h. Siswa menuliskan } 8 \text { kemungkinan } \\
\text { panjang rusuk } 12 .\end{array}$ & $\begin{array}{l}3 \\
10\end{array}$ & $\begin{array}{l}8,6 \\
17,1 \\
14,2\end{array}$ \\
\hline
\end{tabular}




\begin{tabular}{|c|c|c|c|c|}
\hline 2. & $\begin{array}{l}\text { Diketahui volume } \\
\text { balok } 48 \mathrm{~cm}^{3} . \\
\text { Carilah rusuk - } \\
\text { rusuk yang } \\
\text { mungkin dengan } \\
\text { volume tersebut! }\end{array}$ & $\begin{array}{l}\text { a. Siswa menuliskan } 4 \text { kemungkinan. } \\
\text { b. Siswa menuliskan } 4 \text { kemungkinan, } \\
\text { namun salah satu jawabannya salah. } \\
\text { c. Siswa menuliskan } 5 \text { kemungkinan. } \\
\text { d. Siswa menuliskan } 6 \text { kemungkinan. } \\
\text { e. Siswa menuliskan } 6 \text { kemungkinan, } \\
\text { namun salah satu jawabannya salah. } \\
\text { f. Siswa menuliskan } 7 \text { kemungkinan. } \\
\text { g. Siswa menuliskan } 8 \text { kemungkinan. } \\
\text { h. Siswa menuliskan } 9 \text { kemungkinan. } \\
\text { i. Siswa menuliskan } 9 \text { kemungkinan, } \\
\text { namun salah satu jawabannya salah. } \\
\text { j. Siswa menuliskan } 12 \text { kemungkinan. }\end{array}$ & $\begin{array}{l}1 \\
5 \\
4\end{array}$ & $\begin{array}{l}8,6 \\
2,9 \\
22,9 \\
20 \\
2,9 \\
14,3 \\
11,4 \\
8,6 \\
2,9 \\
5,7\end{array}$ \\
\hline 3. & $\begin{array}{l}\text { Lihatlah gambar } \\
\text { segitiga sama sisi } \\
\text { dibawah ini! } \\
\text { Buatlah minimal } \\
5 \text { segi tiga kecil } \\
\text { didalam segi tiga } \\
\text { sama sisi! }\end{array}$ & $\begin{array}{l}\text { a. Menuliskan kurang dari } 5 \text { jenis segi } \\
\text { tiga, kemudian mengelompokannya } \\
\text { berdasarkan sudut dan sifat sisinya } \\
\text { dengan benar. } \\
\text { b. Menuliskan kurang dari } 5 \text { jenis segi } \\
\text { tiga, kemudian mengelompokannya } \\
\text { berdasarkan sudut dan sifat sisinya } \\
\text { namun dalam jenis tertentu tidak } \\
\text { benar. } \\
\text { c. Menuliskan } 5 \text { jenis segi tiga, kemudian } \\
\text { mengelompokannya berdasarkan sudut } \\
\text { dan sifat sisinya dengan benar. } \\
\text { d. Menuliskan } 5 \text { jenis segi tiga, kemudian } \\
\text { mengelompokannya berdasarkan sudut } \\
\text { dan sifat sisinya namun dalam jenis } \\
\text { tertentu tidak benar. } \\
\text { e. Menuliskan } 10 \text { jenis segi tiga, } \\
\text { kemudian mengelompokannya } \\
\text { berdasarkan sudut dan sifat sisinya } \\
\text { dengan benar. jenis segi tiga, } \\
\text { f. Menuliskan } 10 \text { jengelompokannya } \\
\text { kemudian sinat dan sifat sisinya } \\
\text { berdasarkan sudut dan } \\
\text { namun dalam jenis tertentu tidak benar. }\end{array}$ & 11 & 11,4 \\
\hline 4. & $\begin{array}{l}\text { Diketahui luas } \\
\text { persegi panjang } \\
240 \mathrm{~cm}^{2} \text {, hitunglah } \\
\text { kemungkinan P } \\
\text { dan L dari persegi } \\
\text { panjang tersebut! }\end{array}$ & $\begin{array}{l}\text { a. Siswa menuliskan } 3 \text { kemungkinan. } \\
b \text {. Siswa menuliskan } 4 \text { kemungkinan } \\
\text { c. Siswa menuliskan } 6 \text { kemungkinan } \\
\text { d. Siswa menuliskan } 6 \text { kemungkinan, } \\
\text { namun salah satu ada yang salah. } \\
\text { e. Siswa menuliskan } 8 \text { kemungkinan } \\
f \text {. Siswa menuliskan } 10 \text { kemungkinan } \\
\text { g. Siswa menuliskan } 12 \text { kemungkinan }\end{array}$ & 8 & $\begin{array}{l}5,7 \\
14,3 \\
22,9 \\
2,9 \\
34,3 \\
17,1 \\
2,9\end{array}$ \\
\hline 6. & $\begin{array}{ll}\text { Apakah } & \text { ada } \\
\text { bagun datar } & \text { lain }\end{array}$ & $\begin{array}{l}\text { a. Ada, tapi tidak memberikan contoh } \\
b \text {. Ada, hanya memberikan } 1 \text { contoh }\end{array}$ & 1 & 2,9 \\
\hline
\end{tabular}




\begin{tabular}{|c|c|c|c|}
\hline $\begin{array}{l}\text { yang luasnya } \\
\text { sama dengan luas } \\
\text { persegi panjang } \\
\text { diatas? berikan } \\
\text { contohnya! }\end{array}$ & $\begin{array}{l}\text { dengan benar. } \\
\text { c. Ada, hanya memberikan } 1 \text { contoh, } \\
\text { tetapi salah. } \\
\text { d. Ada, memberikan } 2 \text { contoh dengan } \\
\text { benar. } \\
\text { e. Ada, memberikan } 2 \text { contoh salah satu } \\
\text { salah. } \\
\text { f. Ada, memberikan } 3 \text { contoh dengan } \\
\text { benar. } \\
\text { g. Ada memberikan lima contoh dengan } \\
\text { benar. }\end{array}$ & $\begin{array}{l}12 \\
7\end{array}$ & $\begin{array}{l}34,3 \\
20 \\
14,3 \\
14,3 \\
11,4\end{array}$ \\
\hline
\end{tabular}

\section{KESIMPULAN}

Untuk mengakses dan memonitor kemampuan berpikir kreatif matematis, maka peneliti menggunakan hasil observasi, dan hasil tes siswa. Dalam proses kegiatan belajar dikelas guru menggunakan pendekatan Contextual Teaching Learning dan menggunakan alat peraga yang tepat untuk memunculkan berpikir kreatif matematis. Dengan pendekatan CTL dan penggunaan alat peraga yang tepat terbukti dapat memunculkan kemampuan berpikir kreatif matematis, hal ini dibuktikan dengan hasil tes, dan observasi yang menunjukan hasil yang signifikan.

\section{REFERENSI}

Depdiknas. (2006). Kerangka Dasar dan Struktural Kurikulum Tingkat Sekolah Dasar/Marasah Ibtidaiyah. Jakarta: Media Pustaka.

Pehnoken, E. (1997). The State-of-Art in Mathematical Creativity. Zentralblatt für Didaktik der Mathematik (ZDM)-The International Journal on Mathematics Education. [Online] Tersedia:http://www.emis.de/journals/ZDM/zdm 973a1.pdf. [13 Desember 2011]

Silver, E. A. (1997). Fostering Creativity through Instruction Rich in Mathematical Problem Solving and Problem Posing. Zentralblatt für Didaktik der Mathematik (ZDM) - The International Journal on Mathematics Education. [Online]. Tersedia di: http://www.emis.dejournals/ZDM/zdm973a3.pdf. ISSN 1615-679X. [15 Januari 2011].

Worthington, M. (2006). Creativity Meets Mathematics. [Online] Tersedia: http://www.childrens-mathematics.net/creativity_meets_mathematics.pdf. Desember 2011]. 